\title{
'N BEOORDELING VAN DIE TOESPRAAK VAN W. A. VISSER 'T HOOFT BY DIE MINDOLO.BERAAD TE KITWE, ZAMBIE MEI-JUNIE 1964
}

\section{INLEIDING}

DS. J. J. STEENKAMP

Vanaf 25 Mei-2 Junie 1964 het die Wêreldraad van Kerke deur sy Departement Kerk en Gemeenskap in samewerking met die South African Institute of Race Relations en die Mindolo Ecumenical Foundation te Kitwe in Zambië ' $n$ beraad gehou wat besin het oor geweldlose en gewelddadige optrede op sosiale en politieke gebied.

Die besprekings het gehandel oor die volgende vier temas:

1. Die moontlikhede om rasseverhoudinge deur politieke aksie te verander.

2. Die moontlikhede om rasseverhoudinge deur ekonomiese aksie te verander.

3. Die veranderinge wat plaasvind in rasseverhoudinge wanneer mag van die een groep na die ander verskuif.

4. Die verandering wat nodig is in die lewe van die kerke met betrekking tot rasseverhoudinge.

Verskeie persone was uitgenooi om referate oor die betrokke temas te lewer. Daar was ook drie aparte toesprake wat elke in bepaalde aktuele tema behandel het. Een hiervan is gelewer deur dr. W. A. Visser 't Hooft, die destydse Sekretaris-Generaal van die Wêreldraad van Kerke. Die tema hiervan was „The Christian's Role in Transforming Society". Sy toespraak word in hierdie werkstuk beoordeel.

Aangesien dit 'n teologiese toespraak was, word dit gemeet aan die Bybels-reformatoriese teologie. Die belangrikheid van die toespraak is daarin geleë dat dit die teologiese deel van die beraad sou uitmaak. Dit is belangrik omdat dit die vraag behandel of ' $n$ Christen aan gewelddadige verset mag deelneem al dan nie. Waarom hierdie vraag behandel word, word in die agtergrond wat hierna gegee word, geskets.

Die toespraak self bestaan uit veertien stellings, elk met 'n meer of minder uitvoerige toeligting. Die toespraak word stelling vir stelling behandel. Vanweë die algemene onverkrygbaarheid van die toespraak en gevolglik ter wille van die duidelikheid van die betoog, word hierdie stellings telkens onder die eerste onderafdeling van elke betrokke punt in vertaalde opsomming weergegee.

Die Mindolo-beraad en die toespraak van Visser ' $t$ Hooft het in Suid-Afrika heelwat reperkussies gehad. Dit word egter nie nou reeds behandel nie, aangesien dit vir 'n vollediger werk beplan word. 


\section{A. Agtergrond}

Die belangrikheid van die toespraak van dr. W. A. Visser 't Hooft by die Mindolo-beraad word beklemtoon deur die agtergrond waarteen dit gesien moet word. Op die 12 de Junie 1964, dus tien dae na die beëindiging van die Mindolo-beraad, het die Hooggeregshof van Transvaal in Pretoria agt persone tot lewenslange gevangenisstraf gevonnis wat die opsienbarende Rivonia-hofsaak beëindig het. ${ }^{1}$ ) Die beweegredes, optrede en oogmerke van Umkonto We Siswe was deeglik onder die aandag gebring van die Mindoloberaad. ${ }^{2}$ )

Die beplanning van die Mindolo-beraad het egter lank voor die Rivonia-hofsaak begin. In ' $n$ insiggewende brief ${ }^{3}$ ) aan dr. Roswell $P$. Barnes (destydse uitvoerende sekretaris van die personeel van die Wêreldraad van Kerke in Amerika) skryf dr. Robert S. Bilheimer (destydse direkteur van die Afdeling Studies van die Wêreldraad van Kerke in Genève) dat die idee om 'n beraad te hou, by hom posgevat het tydens die vergadering van die beplanningskomitee van die A.A.C.C. wat gehou is by die Mindolo Ecumenical Foundation te Kitwe in Zambië (destyds Noord-Rhodesië). Dié vergadering was beplan vir die tydperk 29 Augustus-5 September 1962..) Teen hierdie tyd was die toer van Nelson Mandela deur Afrika om ondersteuning vir Umkonto We Siswe by Afrika-state te verkry, reeds beëindig ${ }^{5}$ ) en was hy vanaf die 5 de Augustus 1962 in die gevangenis. $\left.{ }^{\circ}\right)$ Met hierdie beraad het Bilheimer beoog om uitvoering te gee aan die planne van die algemene vergadering van die Wêreldraad van Kerke in 1961 te Nieu-Delhi met betrekking tot studies oor geweldloosheid (non-violence) in rasse-verhoudinge vanuit in Christelike oogpunt. ${ }^{7}$ ) Van die idee wat by hom posgevat het, skryf Bilheimer:

„The Rhodesias and South Africa are the place in the world where the issue of non-violence and violence is most pressing, as you know. Why not have a consultation at Mindolo bringing about 50 carefully chosen people together

1) H. H. W. de Villiers, Rivonia, Johannesburg 1964, bl. 34.

2) Z. K. Matthews, The road from non-violence to violence, gepubliseer in Race Relations in Ecumenical Perspective. Genève 1964, no. 5, bl. 19 vv.

3) In my besit is ' $n$ groot hoeveetheid gefotostateerde briewe, verkry uit die argief van die Wêreldraad van Kerke in Genève met toestemming van die bibliotekaris, dr. A. J. van der Bent. Hierna word na hierdie versameling verwys as Briewe. In verband met die idee van Bilheimer, vgl. Briewe, Bilheimer aan Barnes, 22 November 1962.

4) Argief van die Wêreldraad van Kerke, Genève. Africa Working Party-lêer, notule van die vergadering van die Africa Working Party 26-27 Februarie 1962, bl. 2.

5) H. H. W. de Villiers, a.w., bl. 35.

6) H. H. W. de Villiers, a.w., bl. 36.

7) Briewe, Bilheimer aan Barnes, 22 November 1962. 
from this area, plus a very few leaders from North America and Europe, thus asking a group in a localized place to do a job on behalf on all." 8 )

Dat Bilheimer by sy besoek aan Mindolo nader kennis gemaak het met mense wat direk betrokke was by of kennis gedra het van die opleiding van terroriste wat toe al plaasgevind het, is nie onwaarskynlik nie. ${ }^{p}$ ) Aanvanklik was die beraad beplan vir op sy laaste, November $1963 .{ }^{10}$ ) Die rede hiervoor gee Bilheimer as volg:

"Z. K. Matthews points out that 1963 will be a very important year in the Rhodesias politically, and that this will force into even more prominence the basic issue of non-violence and violence in African strategy. The course of these developments will have a tremendous influence in South Africa; even now, strategy there is going away from Luthuli and more and more toward violence, as you know. Thus there is a real element of time urgency in the whole." ${ }^{11}$ )

Wat die finansiële sy van die saak betref, was dit duidelik dat dit 'n duur beraad sou word. Om dit te kon bolwerk, sou hulle iewers moes gaan aanklop. Bilheimer skryf:

"Second, appeal to Hochchild brothers in Wall Street - copper in S.A., Congo and so on. " ${ }^{12}$ )

Hieruit word duidelik dat dit nie net die bekommernis oor die rasseprobleem in Suidelike Afrika was wat aanleiding tot die beraad gegee het nie; ander belange was in aanmerking geneem.

Visser ' $t$ Hooft het reeds van die begin af kennis gedra van Bilheimer se plan. Hy was baie ingenome daarmee. ${ }^{13}$ ) Hy sou dan ook later ' $n$ bepaalde rol moes vervul by die beraad. ' $n$ Aanduiding van wat dit moes wees, vind ons in Bilheimer se brief. Bilheimer het by sy vermelde besoek aan Mindolo met Fred van Wyk van die S.A.I.R.R. gepraat oor sy planne vir die beraad en versoek dat die S.A.I.R.R. hom behulpsaam moes wees. Hierop het Quintin Whyte (destydse direkteur van die S.A.I.R.R.) geantwoord met 'n brief waarby 'n voorlopige ontwerp vir ' $n$ sodanige beraad ingesluit was. ${ }^{11)}$ Hiervan skryf Bilheimer:

.He has taken this frightfully seriously, and I think has produced a good outline, a good list of participants, and very suggestive ideas about leadership - though very weak on the theological and church side. Clearly, however, a conference of this calibre would be very important." ${ }^{15}$ )

\footnotetext{
8) Briewe. Bilheimer aan Barnes, 22 November 1962.

\$) H. H. W. de Villiers, a.w., bl. 87.

10) Briewe, Bitheimer aan Barnes, 22 November 1962.

11 Briewe, Bitheimer aan Barnes, 22 November 1962

12) Briewe, Bitheimer aan Barnes, 22 November 1962.

1:3) Briewe, Bilheimer aan Barnes, 22 November 1962.

14) Briewe, Whyte aan Bilheimer, 11 Oktober 1962.

15) Briewe, Bilheimer aan Barnes, 22 November 1962.
} 
Dit sou van die begin af ' $n$ geslote konferensie wees. ${ }^{16}$ ) Visser 't Hooft se deelname aan die beplanning was nie gering nie. By ' $n$ gesprek oor die beraad wat gevoer was tydens die stigtingsvergadering van die A.A.C.C. te Kampala in April 1963, waar hy teenwoordig was, word ooreengekom dat sprekers vir die beraad eerder uit Europa (Duitsland of Holland) verkry moes word as uit die V.S.A. Dit moes gedoen word „to win support of the Dutch Reformed groups rather than as a criticism of particular American or English speakers". ${ }^{15}$ ) Hiermee was die moontlikheid vir Visser 't Hooft se persoonlike optrede by die beraad reeds daargestel. Aanvanklik sou hy vanweë ' $n$ tydsbepaling wat vir hom onmoontlik was nie deelneem nie, maar nadat die datum op 25 Mei-2 Junie 1964 vasgestel is , sou hy uitgenooi word om as spreker op te tree. Hiervan skryf Bilheimer op 21 Oktober 1963 aan Quintin Whyte en dr. Donald M'Timkulu (destydse Sekretaris-Generaal van die A.A.C.C.) as volg:

,I know he would like to attend. Do you agree a) that he be invited, b) that he be invited to give the address on theology? He would be excellent for the latter, not only because of his general knowledge, but because of his work during the years 1939-1945." ${ }^{18}$ )

M'Timkulu het toegestem tot die uitnodiging van Visser ' $t$ Hooft en bygevoeg:

„For many other good reasons I would strongly support the suggestion that he be asked to do this." ${ }^{19}$ )

Dit is dus duidelik dat Visser 't Hooft ' $n$ teologiese basis aan die beraad moes gee, veral waar die mede-beplanners (Whyte e.a.) nie soveel klem op die kerklike en teologiese aspek gelê het nie. Verder was dit nie énige toelogiese basis nie, maar een wat gespruit het uit sy ondervinding ten tyde van die Tweede Wêreldoorloog. $\mathrm{Hy}$ het deelgeneem aan verskeie optredes van verset teen Duitsland. ${ }^{20}$ ) Hierdie ondervinding sou vir die beraad van waarde wees.

So is Visser 't Hooft dan formeel op 8 November 1963 uitgenooi om as spreker op te tree. ${ }^{21}$ ) In hierdie uitnodiging word egter genoem dat hy moet praat oor ,,some of the theological-ethical problems that people face as they struggle for social change in a totalitarian or quasi totalitarian situation". Hier word nie expressis verbis van rasse-verhoudinge gepraat nie, wat die vermoede laat ontstaan dat

16) Briewe, Bilheimer aan James Oglethorpe, 28 November 1962.

1i) Argief van die Wêreldraad van Kerke, Genève, Mindolo-lêer, Memorandum on the Discussion concerning the Race Consultation for Southern Africa, bl. 2.

18) Briewe, Bilheimer aan M'Timkulu/Whyte, 21 Oktober 1963.

1:) Briewe, M'Timkulu aan Bilheimer, 25 Oktober 1963.

2i1) Vgl. hiervoor veral die hoofstukke $21-25$ in W. A. Visser it Hooft, Memoires. Amsterdam 1971.

21) Briewe, Bilheimer aan Visser 't Hooft, 8 November 1963. 
rasse-verhou dinge nie primêr ge-ag is nie. Dit was immers 'n "Southern Africa Christian Consultation on Race Relations". Die sekondêre belang by rasse-verhoudinge, word duidelik geillustreer in die subtitel van die program vir die beraad: "Christian Practice and Desirable Action in Social Change and Race Relations." ${ }^{22}$ )

Bilheimer het die personeel van die Wêreldraad van Kerk teen die einde van 1963 verlaat en $P$. Abrecht het die organisasie van die Mindolo-beraad oorgeneem. W. H. Crane moes die Bybelstudie vir die beraad waarneem en nadat sy voorstelle in verband met sy werk via Bilheimer, by Abrecht uitgekom het, het Abrecht dit met Visser 't Hooft bespreek. Volgens Abrecht was te veel klem gelê op .justification of the nation and not enough on reconciliation of the nations ${ }^{\prime 23}$ ) nie. Hierop het Visser 't Hooft geantwoord dat die ",'word' approach" in Mexiko baie suksesvol was en dan noem hy ook die volgende begrippe wat belangrik sou wees vir die studie: .Covenant - People of God - Justice - Reconciliation - Man (all pantes $=$ humanity) - New Creation - Babylon + Whitsun - ${ }^{.24}$ ) Dit is opmerklik dat van die sondeval en 'n Christologiese verstaan van geregtigheid en versoening niks gesê word nie. Dit gee ' $n$ aanduiding van wat verwag kon word van sodanige Bybelstudie. Verder word hiermee op baie pertinente wyse die Bybel in diens gestel van besondere oogmerke wat bereik moet word.

Soos reeds gemeld, sou die konferensie van die begin af geslote wees. Dit moes nie veel publisiteit, indien enige, kry nie. Die rede hiervoor was dat daar oor geweld en geweldlose optrede besin sou word. Strategies sou dit 'n belemmerende uitwerking hê op die moontlike invloed van die beraad indien dit voor die tyd algemeen bekend sou wees wat in die beraad ter sprake sou kom. Verder was dit vooraf duidelik dat die bekendmaking van die hooftema, sake vir die Suid-Afrikaanse deelnemers moeilik sou maak. Bilheimer was hiervan bewus en hy stel dit dan ook aan Abrecht soos volg:

I doubt if it is wise to be more explicit about the themes at this stage and certainly not to mention in the statement of them the violence, non-violence problem. Whatever we print must be sufficiently safe so that it can not be used against our friends from South Africa." ${ }^{25}$ )

Die geheimhouding oor die beraad het egter nie geëindig toe die beraad verby is nie. Daar is voortgegaan om veral die behandeling van geweld en geweldloosheid dig te hou. In hierdie verband waarsku Abrecht vir Barnes op 3 Julie 1964:

22) Argief van die Wêreldraad van Kerke, Genève, Mindolo-lêer.

2:) Briewe, Abrecht aan Visser 't Hooft, 4 Februarie 1964.

24) Hierdie antwoord het Visser 't Hooft op Abrecht se brief, genoem in voetnoot 23 , teruggestuur.

25) Briewe, Bilheimer aan Abrecht, 14 Februarie 1964. 
„Discretion must be used in identifying individual speakers who appeared before the Consultation. We do not want it publicized that Visser 't Hooft spoke about the theology of a resistance ethics, or that Z. K. Matthews spoke on the subject 'From Non-violence to Violence in South Africa: Or that Mondlane spoke on Mozambique liberation. Such facts might be given in a very intimate circle of the National Council of Churches' leadership but not in any other circles. While the South African government probably knows these facts also, the wide publication by us of such facts could endanger the people who participated from South Africa or could endanger the passport of Matthews. ${ }^{.26}$ )

Dit is dus duidelik dat diegene wat die beraad georganiseer het, geweet het dat hulle besig was met sake wat nie net hoogs delikaat was nie, maar ook dat hulle oor inligting beskik het wat vir die regerings in Suidelike Afrika (ten minste dié van Mosambiek en Suid-Afrika) ter wille van landsveiligheid van groot waarde was. Die toespraak wat Mondlane gelewer het, is doelbewus nie op skrif gestel nie, aangesien dit te gevaarlik sou wees. ${ }^{27}$ ) Om hierdie toespraak te kon lewer, is Mondlane deur Abrecht persoonlik van Dar-es-Salaam na Kitwe gebring." ${ }^{27}$ ) Die toesprak van Visser 't Hooft en Matthews is tesame met ander wat gelewer is op die beraad, gepubliseer in die Julie-uitgawe van 1964 van „Race Relations in Ecumenical Perspective". In hierdie uitgawe word dit verswyg dat dit húlle toesprake was. By Visser 't Hooft se toespraak word die skrywer alleen aangedui as „by a theologian”, terwyl by Matthews s'n heeltemal niks staan nie.. ${ }^{28}$ ) Die weglating van hulle name het die beskerming van die skrywers ten doel gehad. ${ }^{29}$ )

As egter in aanmerking geneem word dat die eerste skote van FRELIMO op 25 September 1964 in die provinsie Cabo Delgado in Mosambiek geval het: ${ }^{* 0}$ en dat Mondlane by die beraad oor "Mozambique liberation" gepraat het,"1) kry die geheimhouding sin. Maar belangriker as dit; was die toespraak van Visser ' $t$ Hooft die woord waarop Mondlane (van wie gesê is dat hy 'n Christian was) ${ }^{32}$ ) gewag het?

\footnotetext{
26) Briewe, Abrecht aan Barnes, 3 Julie 1964.

27) Persoonlike mededeling van Abrecht aan my.

28) Race Relations in Ecumenical Perspective, Genève 1964, no. 5, bl. 3 en 4 resp.

29) Briewe, Abrecht aan Barnes, 21 Julie 1964.

31) E. Mondlane, Kampf um Mozambique, Frankfurt 1970, bl. 24.

31) Briewe, Abrecht aan Barnes, 3 Julie 1964.

32) W. A. Visser 't Hooft, a.w., bl. 263.
} 


\section{B. Die Toespraak}

\section{Inleiding:}

In sy inleiding stel Visser 't Hooft die moontlikheid dat die tema wat hy wil behandel, op twee maniere benader kan word. Die een manier is om net een aspek van die saak te behandel. Die ander manier, wat hy kies, is om die probleem as 'n geheel te benader. Hy doen dit ,because we are today in a period of confusion about social ethics and we can therefore take almost nothing for grant$\mathrm{cd}^{\prime \prime} .{ }^{33}$ ) Daar bestaan dus verwarring oor sosiale etiek. As gevolg van hierdie verwarring behandel Visser 't Hooft die tema as 'n geheel. Volgens hom kan niks as 'n uitgemaakte saak beskou word nie, omdat daar verwarring oor sosiale etiek bestaan.

Die sosiale etiek waarvan hy praat, noem hy nie spesifiek 'n Christelike etiek nie. 'n Ware Christelike word nie moontlik geag nie, as dit nie onafskeidelik saamhang met 'n ware Bybels-gefundeerde dogmatiek nie. ${ }^{34}$ ) Christelike etiek is dan geloofsetiek, Bybelse etiek. ${ }^{35}$ ) 'n Mens kan ook sê dat die Christelike etiek gegrond is in die Wil van Christus ${ }^{30}$ ) Indien aangeneem sou word dat Visser 't Hooft van Christelike etiek praat, sou die gevolgtrekking seker korrek wees dat hy sou sê dat daar verwarring bestaan ten opsigte van dié etiek wat grond in die geloof, dié etiek wat grond in die Bybel; verwarring ten opsigte van die Wil van Christus. Indien die sosiale etiek waarvan hy praat, nie 'n Christelike etiek is nie, ontstaan die vraag met reg: waarin grond hierdie etiek?

Dit verbaas dus enigsins dat Visser 't Hooft, nadat hy van verwarring gepraat het, in die eersvolgende sin die aandag vra vir die „fundamental points which a very short catechism of social ethics should contain". Daar bestaan dus "n grond vir die sosiale etiek waarvan hy praat. Dit verskerp die vraag na welke grond daar verwys word, afgesien van die feit dat hy homself hier implisiet deeglik weerspreek, want indien daar 'n basis vir sosiale etiek sou wees, waar kom die verwarring dan vandaan?

Soortgelyke verwarring en onsekerheid word reeds uit die vroeëre geskiedenis van die ekumeniese beweking aangemeld. So vind ons in die rapport oor kerk en gemeenskap van die vergadering van die Life and Work-beweging, wat te Oxford in 1937 gehou is, die volgende:

33) W. A. Visser 't Hooft, The Christian's Role in Transforming Society, gepubliseer in Race Relations in Ecumenical Perspective, Genève 1964. no. 5 , bl. 3 .

34) Vergelyk G. Brillenburg Wurth, Christelike Sedeleer, Pretoria 1967, bl. 8.

3i) Vergelyk G. Brillenburg Wurth, a.w., bl. 9.

36) Vergelyk $H$. de Vos, Inleiding tot de Ethiek, Nijkerk 1959, bl. 134. 
„Today, however, as probably only once or twice before in human history, the foundations themselves are shaken. Traditional pieties and loyalties and standards of conduct have lost their unquestioned authority; no new ones have taken their place. As a result, the community life of mankind has been thrown into confusion and disintegration. ${ }^{.3 i}$ )

Dit lyk dus of die verwarring wat Visser 't Hooft van praat, reeds vroeër bekend was. Soos by hom, het hierdie verwarring ook bestaan ten opsigte van die sosiale etiek. Miskien moet die antwoorde op ons vrae in die byvoeglike naamwoord „sosiaal” gesoek word.

Hierdie vrae word verder no gdringender as Visser ' $t$ Hooft in die volgende paragraaf van die inleiding twyfel uitspreek „,whether the Church can give any substantial help to men and women who have to face such agonishingly perplexing questions as have been formulated in other papers for this conference". Hierdie twyfel oor die moontlikhede van die kerk hang direk saam met die verwarring oor sosiale etiek, want as die Christelike etiek onafskeidelik saamhang met ' $n$ ware Bybels-gefundeerde dogmatiek beteken dit dat die Christelike etiek onafskeidelik saamhang met dit wat die kerk glo ${ }^{38}$ ) Wat die kerk glo, vind uitdrukking in die simboliese skrifte ${ }^{30}$ ) Hierdie belydenisse van die kerk se oervorm het gelui: „,Kyrios Jesous Christos, Jezus Christus is Heer!" +0 ) Sou 'n mens dan op logiese wyse die afleiding kan maak dat die verwarring waarvan Visser 't Hooft praat, bestaan met betrekking tot die belydenis dat Jesus Christus die Heer is? Dit wil so voorkom. In elk geval is dit duidelik dat daar 'n bepaalde vloeibaarheid in sy benadering is, insoverre dit betrekking het op die geloofsleer, die belydenis van die kerk. Die gevolg hiervan sal dan ook ' $n$ verwarring wees, aangesien die geloofsleer, die belydenis van die kerk ' $n$ vaste vorm daarstel vir die Christelike etiek en as daarvan afgewyk word of wanneer vry daarvan opgetree word, word alle sedelike handelinge subjektief gerelativeer.

Visser 't Hooft stel dit vervolgens dat daar gedurende die Tweede Wêreldoorlog en later jare sodanige internasionale- en rasse-botsings was, dat dit die kerk voor dilemmas gestet het waarop die sosiale etiek geen antwoord wis nie. Hy sê alle aksie het in ' $n$ etiese doodloopstraat beland waarin ,inaction is the most

3i) J. W. Turnbull (red.). Ecumenical Documents on Church and Society, Genève 1954, bl. 49-50.

38) Vergelyk G. C. van Niftrik, Kleine Dogmatiek, Nijkerk 1961, bl. 16.

39) Vergelyk A. D. R. Polman, Onze Nederlandsche Geloofsbelijdenis, Franeker s.j., bl. 53.

40) G. C. van Niftrik, a.w., bl. 159. 
irresponsible attitude of all". Dit is inderdaad 'n logiese voortvloeisel van etiese subjektiwisme. Dit gaan dus nie om wát daar gedoen word nie, of hóé dit gedoen word nie, solank daar net iets gedóén word. Hieruit word dit duidelik dat etiese subjektiwisme tot aktiwisme gelei het. Aangesien die Christelike geloof van die onverdiende genade van God leef en nie van menslike prestasies nie, val alle aktiwisme dus daarbuite. ${ }^{+1}$ )

1.1 Nadat Visser 't Hooft die onmag van die kerk aangekondig het, begin hy sy kategismus oor sosiale etiek met die stelling dat Christene in die wêreld gestuur is om van die Heerskap van Christus te getuig met woord en daad. Hy sê die wêreld se lewe is grootliks gevorm deur sosiale en politieke faktore en die Christene is geroepe om hulle Heer binne hierdie gebied te dien soos in enige ander.

1.2 Die Christene moet dus van die Heerskap van Christus getuig ne Hom op sosiale en politieke gebied dien soos op enige ander. Die betekenis hiervan word duideliker as Visser 't Hooft in sy uitvoering noem dat die kerk grootliks verantwoordelik is vir die "kettery" dat die politiek ' $n$ wêreldlike gebied is wat met die Christelike geloof niks te doen het nie, aangesien die kerk gedurende lang tydperke die Koningskap van Christus nie in sy volheid en omvatten dheid geproklameer het nie.

Dit is duidelik dat Visser't Hooft hier onderskei tussen die kerk en Christene. Christene moet dit doen wat die kerk nagelaat het. Christus is egter die Hoof van die kerk en die kerk is die liggaan van Christus (Rom. 12:4 vv.; I Kor. 10:16 vv.; 12:12 vv.; Kol. 1:18, 24; Ef. 1:22 vv., 4; 12, 5:23, 29 vv.). Eers nadat die kerk as die liggaam van Christus bely is, volg die prediking in die wêreld. ${ }^{+2}$ ) Die Christene maak dus die kerk uit. Daarom is 'n onderskeiding tussen Christene en die kerk, as sou daar twee groothede kon bestaan, onskriftuurlik.

Aangesien die kerk die liggaam van Christus is, kan daar dus nie van die Heer gepraat word nie, as daar nie ook van die kerk gepraat word nie. Die kerk, wat die Here $s^{\prime} n$ is, staan onder volstrekte gesag van Christus. Christus oefen sy heerskappy oor die enkeling uit binne die gemeenskap van die kerk. Die gelowige leef onder die heerskappy van Christus alleen as lid van die gemeente. „'Mijn Heer' is Jezus alleen, omdat Hij, 'onze Heer is" +3 ) Daarom is die belydenis van die gelowige dat Jesus Christus die Heer is, altyd ' $n$ belydenis vanuit die gemeenskap

41) Vergelyk die Heidelbergse Kategismus, vraag 21 in Belydenisskrifte, Gebede en Formuliere van die Nederduistch Hervormde Kerk van Afrika, Elsiesrivier 1963, bl. 35. Hierna word hierdie uitgawe aangehaal as Belydenisskrifte.

42) Vergelyk G. van der Leeuw, aangehaal by G. C. van Niftrik, a.w., bl. 275.

43) G. C. van Niftrik, a.w., bl. 160. 
van die kerk. Christene word dan nie geroep om buite die kerk om van Christus te getuig nie, maar juis om binne die kerk, dus as kerk in die wêreld te getuig.

Hierdie belydenis van die kerk geskied nie sonder 'n duidelike eskatologiese binding nie.

,.Hij is de Heer der Kerk, over welke Hij met volstrekt gezag gebiedt, als eschatologisch teken in het midden dezer oude wereld." ") Die getuienis van die gelowige moet dus altyd die getuienis wees van die kerk wat wagtend in hierdie wêreld verkeer. Hierdie wêreld word dan heilsaam gerelativeer en in hierdie sin moet die opdrag van die kerk ten opsigte van die sosiale en politieke probleme verstaan word. Hoewel dit geen wêreldmyding beteken as daar gesê word dat die kerk nie „van hierdie wêreld" is nie, moet dit beklemtoon word dat "hierdie wêreld" nie die einddoel van die kerk is nie. Dit beteken inderdaad nie dat die kerk buite hierdie wêreld bestaan nie, maar die kerk behoort nie aan die wêreld nie.

"As in Paul the hagioi, those who belong to the ekklêsia, are not part of the kosmos, so in Jn. believers are not ek tou kosmou...

In John's teaching, as in that of Paul and James, the Church does not belong to the world, though the world is its sphere of operation. ${ }^{.55}$ )

Visser 't Hooft stel in hierdie eerste stelling nie 'n duidelike eskatologiese binding daar van die getuienis van die Christene nie en die vermoede ontstaan dat hy aan individuele Christene 'n innerwêreldlike opdrag gee op sosiale en politieke vlak; iets wat die kerk deur wêreldontvlugting nagelaat het om te doen. Hierdie innerwêreldlike opdrag noem hy wel onder die proklamasie van die heerskap van Christus, maar dit moet bevraagteken word of hy dit ook stel onder die eskatologeise perspektief, aangesien hy die onderskeid tref tussen kerk en Christene. Wat die ekumeniese beweging betref, vind ons reeds in die hoofrapport van die Oxford-vergadering van Life and Work in 1937 'n verdeling van die arbeidsveld van kerk en Christene. ${ }^{40}$ ) Ook dáár word 'n definitiewe werksaamheid op sosiale en politieke vlak aan die Christene opgedra. Hierdie verdeling moet sekerlik gesien word vanuit die slagspreuk wat die beplanningskomitee van die Stockholm-vergadering van 1925 (waar die Life and Work-beweging begin het) gebruik het, naamlik „Doctrine devides, service unites"..4) Hier word alreeds die losmaking van etiek en geloofsleer duidelik wat later by Visser ' $t$ Hooft ook aangetref word.

14) G. C. van Niftrik, a.w., bl. 160.

45) H. Sasse, KOSMOS, artikel in G. Kittel (red.). Theological Dictionary of the New Testament, Grand Rapids 1968, Bd. III, bl. 895.

46) J. W. Turnbull (red.), a.w., bl. 84 vv.

17) J. W. Turnbull (red.), a.w., bl. 1. 
2.1 Visser 't Hooft se tweede stelling hou in dat die Christen se getuienis in die politiek nie slegs ' $n$ persoonlike morele handhawing is nie, maar dat die Christen die maatskaplike strukture moet waardeer, dié strukture wat ongeregtigheid huisves moet opponeer, en moet werk vir 'n gedaanteverandering van die maatskappy sodat die mens in staat gestel kan word om sy roeping te vervul as verantwoordelike skepsel van God vir wie Christus gesterf het.

2.2 Duidelik wil Visser ' $t$ Hooft die een saak doen en die ander nie laat nie. Hy beklemtoon egter die werk van die Christen in die maatskappy en dié taak stel hy negatief, naamlik om die strukture wat ongeregtigheid huisves, teen te staan. Die verandering van die maatskappy is die voorwaarde vir die volvoering van die roeping van die mens. Dit wil sê 'n mens kan nie aan sy roeping ten volle beantwoord so lank as wat daar verhinderende faktore in die maatskappy bestaan nie. Nou ontstaan die vraag, wat die roeping van die mens dan sou wees? As dit is wat Visser ' $t$ Hooft onder 1 genoem het naamlik die diens van die Heer op sosiale en politieke vlak, dan weerspreek hy homself inderdaad, aangesien volgens 1 'n vervulling van die roeping tog moontlik sou wees, al is daar verhinderende faktore. Wat egter van groot belang is, is dat hier ' $n$ duidelike klemverskuiwing plaasvind van die mens na die struktuur. Die mens moet nie alléén meer aangespreek word vanweë sy sonde nie, maar die struktuur moet ook daaronder betrek word. By implikasie verstaan ' $n$ mens hiermee, dat indien die strukture van die maatskappy van ongeregtigheid ontdaan is, die mens dan vanself sy roeping sal kan vervul. Dit is dus nie die mens wat die ongeregtigheid huisves nie, maar die strukture van die maatskappy. Hier word die mens as inherent goed daargestel. Logies sou 'n mens kon antwoord dat die strukture tog nie anders ontstaan het as deur die mense nie en dat die strukture dus maar net die stempel dra van die mens se ongeregtigheid. Die Woord van God leer dit egter baie duidelik (Gen. 6:5, 8:21). Hierdie leer het dan ook neerslag gevind in die belydenis van die Hervormde kerke wat by Calvyn geleer het. ${ }^{48}$ )

Die rede vir hierdie beskouing van Visser 't Hooft moet waarskynlik gesoek word in sy opleiding as leerling van $\mathrm{K}$. H. Roessingh en G. J. Heering wat op hom 'n remonstrantse stempel gelaat het. Veral 'n studie van Troeltsch het hom daartoe gebring om die Christen se taak op sosiaal-ekonomiese vlak te sien. ${ }^{49}$ )

48) Vergelyk die Nederlandse Geloofsbelydenis Artikel XIV in Belydenisskrifte, bl. 9. Sien ook die Heidelbergse Kategismus vraag 8 in Belydenisskrifte, bl. 32 .

49) W. A. Visser 't Hooft, Memoires, Amsterdam 1971, bl. 19. 
Wanneer Visser 't Hooft in sy uitvoering weer die kerk van wêreldontvlugting beskuldig sodat dit eers die kommunisme en die nasional-sosialisme was wat die kerk tot sosiale en politieke kritiek aangewakker het, moet hierdie bewering weer in die geskiedenis van die ekumeniese beweging gesoek word. Om dit uit die geskiedenis van die kerk en veral die reformatoriese kerke te wil bewys, gaan te ver, aangesien die verandering wat die Hervorming spesifiek in Europa meegebring het, ' $n$ té duidelike taal spreek.

So vind ons uit die berig van 'n ekumeniese studiekonferensie vir Oos-Asië wat in 1952 te Lucknow gehou is, die volgende:

.We are concerned with social justice, that is to say with the development of social conditions in which human dignity and freedom can find their expression as befits the nature and destiny of man as a child of God. Communism has awakened and challenged our conscience to see the need for action." ${ }^{511}$ )

Die tweede stelling van Visser ' $t$ Hooft is dus grootliks terug te vind by die ekumeniese konsensus, eerder as dat dit getuig van 'n kennis van die werk wat die kerk in die verlede veral deur sy diakoniese diens gedoen het.

'n Verwysing na die taak van die leke, herinner aan die onderskeiding tussen kerk en Christen. Wat die kerk en veral dan sy ampsdraers nie gedoen het nie, moet die leke nou aanpak en volvoer. 'n Christendom wat los van die kerk opereer, moet die werk van die kerk doen.

3.1 Die wapentuig waarmee die Christen die maatskaplike lewe binnetree, bestaan vir Visser 't Hooft nie uit 'n wetboek, uit algemene morele resepte of 'n sosiaal-etiese sisteem wat gebaseer is op onveranderlike ordes van die skepping of die natuurreg nie.

3.2 Dit is sodat die gelowige nie oor ' $n$,pasklaar program" beskik wat vir hom gedetailleerde aanwysings gee oor sy konkrete lewe nie. Dit is ook sodat die gelowige nie die basis van sy handeling in die skeppingsordes of natuurreg vind nie. Daar bestaan dus geen protestantse kasuistiek nie. Maar dit is tog sodat veral die Calvinisme erns gemaak het met die tertuis usus legis. Dit beteken ook weer geensins dat hier 'n sisteem opgestel is wat tussen die Heilige Skrif en die mens ingeskuif het nie. ${ }^{51}$ ) Veral Calvyn het geen geslote etiese sisteem gehad nie. Aan die besware van Visser 't Hooft in verband met ' $n$

50) J. W. Turnbull, a.w., bl. 144.

51) Vergelyk B. J. Engelbrecht, Die prinsipiële patroon van die Calvinisme in S.A., referaat gelewer by ' $n$ simposium van die Instituut vir die Bevordering van Calvinisme te Potchefstroom op 10 April 1969, bl. 1 vv. 
wetsisteem vir die evangeliese etiek, sal dus slegs dán gehoor gegee kan word, wanneer hy sou aantoon dat in die evangeliese etiek 'n wetsisteem sou bestaan wat nie ,ten nouste saamhang met die regte visie op die konfessie en met die regte konfessionele praktyk"s2) nie. Aangesien hy die kerk weer beskuldig van wettisisme word dit duidelik dat hy 'n sosiale etiek voorstaan wat los van die belydenis van die kerk staan. Opvallend is verder die beklemtoning van die persoonlike beslissing en die persoonlike verantwoordelikheid binne die Christelike lewe. Aangesien enige persoonlike beslissing van die gelowige in en deur die geloof onder leiding van die Heilige Gees geneem word ${ }^{53}$ ) en 'n sodanige pneumatologiese binding nie by Visser 't Hooft te vind is nie, is die moontlikheid tog daar dat hy by die mens die moontlikheid veronderstel tot selfstandige etiese oordeel. Is dit nie dalk juis in die natuurreg en in die sogenaamde skeppingsordes wat hy meen te bestry, dat hy die moontlikhede van die mens vind nie?

4.1 Visser 't Hooft sê die taak van die Christen is om die goddelike geskiedenis in die sekulêre geskiedenis te verteenwoordig. Sy besluite moet geinspireer wees deur die onveranderende konteks van God se plan soos wat dit in die goddelike dade in die Skrif openbaar is. Die bepalende faktor is die goddelike geskiedenis en nie die konkrete lewenssituasie van die mens nie.

4.2 Hier vind ons 'n verbinding van die Christelike etiek aan die Skrif. Dat die mens egter die goddelike geskiedenis in die wêreldlike geskiedenis moet verteenwoordig, stel dit duidelik dat die mens nog steeds ' $n$ selfstandige besluit moet neem. Hierdie besluit mag wel geneem word soos wat Visser ' $t$ Hooft sê, ,inspired by the eternal, unchanging context of God's plan as revealed in the great divine deeds recorded in Scripture", maar dit beteken nog nie dat met ,inspired" die leiding van die Heilige Gees bedoel is nie.

Verder is dit sodat die "goddelike geskiedenis" en spesifiek dit wat in die Bybel openbaar is, direkte handeling van God met hierdie wêreld is. Daardie handeling het nog nie opgehou nie. Dit word bely deur die kerk wanneer die kerk spreek oor die voorsienigheid van God. Calvyn sê in hierdie verband die volgende:

52) B. J. Engelbrecht, a.w., bl. 2.

53) Vergelyk C. J. Mans, Die Owerheid in die Nuwe Testament en by die Reformatore, artikel in Hervormde Teologiese Studies, Krugersdorp 1962, Jrg. 18, Afl. III, bl. 91. 
.,Atque huc se protendit divinae providentiae vis, non modo ut rerum eventus succedant quemadmodum expedire prospexerit: sed ut voluntates quoque hominum eodem tendant." ${ }^{-5}$ )

Daarom kan die mens (Christen) beswaarlik as verteenwoordiger van die "goddelike geskiedenis" optree. Hy is nog steeds self objek van die handeling van God in die wêreld. Visser ' $t$ Hooft gee dus hier aan die mens 'n selfstandigheid wat hom nie toekom nie.

5.1 Van die "goddelike geskiedenis" in die Ou en Nuwe Testamente ontvang die Christen 'n perspektief op die ontwerp van God vir die wêreld en wysers of tekens oor die aard van Christelike gehoorsaamheid in die maatskappy. Wat die Christen van Gods openbaring leer, is geen resep vir sy gedrag nie. Hy leer iets baie belangriker, naamlik hoe die realiteite van die menslike lewe in die lig van Gods ewige wil lyk.

5.2 Hierdie vyfde stelling van Visser 't Hooft klink oënskynlik goed. Selfs die interpretasie wat hy gee dat die verstaan van die Deuteronomiese wet geen biblisistiese wettisisme impliseer nie, is goed in lyn met die Bybelsreformatoriese teologie.

So is dit ook aanvaarbaar dat die Bergpredikasie om gehoorsame interpretasie vra. Dieselfde beswaar van $4.2 \mathrm{kom}$ egter hier van toepassing, naamlik dat aan die mens 'n sekere selfstandigheid toegeken word wat hom nie toekom nie. Dit gaan daarom dat aan die mens die moontlikheid gegee word om selfstandig die wil van God te kan leer ken.

Hierdie selfstandigheid kom duidelik na vore wanneer Visser ' $t$ Hooft sê: „And we must ask again and again: How must I live and act as a representative of such a King..." Hy maak dus van elke gelowige ' $n$ pous. En net so moeilik as wat dit vir die Roomse eweknie is om ex cathedra te spreek, so moeilik word dit vir die evangeliese pousies om vry te kom van die plig om selfstandige besluite te neem. Die evangelie word dus ' $n$ gevaarlike wet, wat op subjektiewe wyse uitgelê en toegepas kan word. Van 'n sodanige vermenging van Wet en Evangelie sê Otto Weber die volgende:

„Wo mit dem Evangelium eine nova lex verbunden, wo Christus zum legislator wird, da besteht der Ansatz dazu, die Welt mit Hilfe des Evangeliums zu wandeln. Wir sind gewohnt, in diesem Falle von 'Schwärmertum' zu sprechen." ${ }^{55}$ )

54) J. Calvyn, Institutio Christianae Religionis, gepubliseer in O.S. III, 295, 25 vv.; II, iv, 6.

55) O. Weber, Grundlagen der Dogmatik, Neukirchen-Vluyn 1964, Bd. II, bi. 413 . 
In sy begrip van die koninkryk van God bestaan daar ook geensins ' $n$ eskatologiese aspek nie. Die Christene is lede van dié koninkryk deur die navolging van Christus. Hier kom weer sterk die selfstandigheid van die mens na vore. Dit is ' $n$ mens wat kan besluit of hy lid wil word van die koninkryk of nie. Hier is dus geen sprake daarvan dat die Heerskappy van Christus as genadehandeling ook heerskappy uitoefen oor die wil van die gelowige nie. Die sekerheid waarin die gelowige mag lewe dat hy nie deur sy eie toedoen nie, maar deur die genadehandeling van God in Christus uitverkore is om deel te hê aan die verwagting van die wederkoms van die Heer van die kerk, bestaan nie in die koninkryk van die mens wat kan kies om lid te wees nie.

Hierdie selfstandigheid van die mens word nog duideliker wanneer Visser ' $t$ Hooft die weg aandui waarlangs die Wil van God geken kan word in 'n konkrete situasie. Hy noem drie dinge wat die mens moet doen. Eerstens moet die mens probeer om die volle implikasies van sy keuse en besluit te verstaan, veral hoe dit ander mense raak. Tweedens moet probeer word om te ontdek welke lig die openbaring van God se handelinge met mense en sy ontwerp vir die mensheid op die situasie werp. Hier is Bybelstudie volgens kerkinterpretasie noodsaaklik. Derdens moet gebid word om insig in God se wil en gereedheid om te gehoorsaam. Hier hang alles af van die realiteit van die persoon se geloof.

Voordat daar dus enige studie van die Woord van God gedoen is, word ' $n$ keuse gemaak en ' $n$ besluit geneem. Daarna volg Bybelstudie en laastens gebed. Eintlik word op hierdie wyse nie na die wil van God gevra nie, maar God word gebruik om die besluit van die mens te sanksioneer. Wanneer hy besluit, sê hy dat alle bronne van kennis en inligting wat beskikbaar is, gebruik moet word. Sy besluit word dus gebaseer op kennis en inligting wat buite Gods Woord om verkry word. Dit gaan hier dus glad nie om die wil van God nie, maar om die besluit van die selfstandige mens.

Brillenburg Wurth stel ' $n$ ander weg daar om tot kennis van die wil van God te kom. Eerstens is 'n deeglike kennis van die Woord van God nodig. Tweedens is die leiding van die Heilige Gees van groot belang om 'n brug te bou van die Woord van God na die roeping van die gelowige in die konkrete situasie. Derdens is die gebed nodig en vierdens moet op die gemeenskaplike Christelike opinievorming gelet word. ${ }^{50}$ ) Hier is geen sprake daarvan dat die mens se besluit eerste moet kom nie. Die kerk leer die wil van God ken soos wat God dit aan die

56) G. Brillenburg Wurth, a.w., bls. $48-49$. 
kerk openbaar het. Die wil van God is een met die mag van God. Hierdie wil van God is ooreenkomstig met sy verbond. ${ }^{.57}$ ) Die wil van God word in Jesus Christus volvoer. ${ }^{58}$ ) In Jesus Christus leer die gelowige dan die wil van God ken. Daarom is die enigste kenbron van die wil van God vir die gelowige die Woord van God. ${ }^{50}$ ) Hierdie Woord leer hy ken deur die leiding van die Heilige Gees, terwyl hy saam met die ganse kerk in deemoed bid: "Laat u wil geskied!"

6.1 Christelike politieke aksie is nie beinvloed deur of utopisme of défaitisme nie. Dis nie utopies nie, omdat dit alle oplossings van maatskaplike probleme as relatief moet beskou. Dis nie défaitisties nie aangesien dit gesteun word deur die geloof dat werk vir die saak van geregtigheid en vrede nie tevergeefs in die Here is nie. So lui die sesde stelling van die kategismus.

6.2 Dit is waar dat die gelowige in sy werk geen utopie wil verwerklik nie. Die gelowige weet dat daar geen ander ryk van saligheid bestaan nie as die koninkryk van God waar volkome vrede heers. Vir die gelowige is die verwerkliking van enige ander staat in die plek daarvan dus iets wat nie onder die regverdigende handeling van God val nie. Sodanige ryke dra die stempel van die sondige mens. Net so is die gelowige geen défaitis nie, aangesien hy onder die belofte van God leef en in die geloof (wat 'n vaste vertroue is) wagtend is op die wederkoms van die Here Jesus Christus.

Visser 't Hooft maak egter sy eie stelling tot niet. Wat die utopisme betref, sien hy reg in dat dit totalitêr van aard is en dat dit 'n aanspraak op absoluutheid maak. As die ware absolute stel hy egter die „superhuman”. Die woord „superhuman" kan in Afrikaans vertaal word met "bomenslike". Daar is geen aanduiding dat met "superhuman" die Verbondsgod van die Bybel bedoel word nie, selfs nie eers 'n afgod nie. ${ }^{60}$ ) Indien Visser 't Hooft die Verbondsgod daarmee bedoel, sou dit beteken dat daar slegs 'n kwantitatiewe verskil tussen God en die mens bestaan (analogia entisl). Dit is vir die gelowige wat weet van 'n analogia fidei onaanvaarbaar. Aangesien „superhuman" egter net „,bomenslik" kan beteken, vervang Visser 't Hooft dus een ideologie met ' $n$ ander en maak daarmee sy stelling tot niet. Hierdie "bomenslike" is vir hom beliggaam in die Christelike geloof. So 'n standpunt toon remonstrantse trekke wat by Visser 't Hooft verwag kan word, veral as dit saam gesien word met sy stelling in 5 dat alles by die gebed

si) O. Weber, a.w., Bd. I. bl. 486.

is) O. Weber, a.w., Bd. l, bl. 579.

i8) B. J. Engelbrecht, a.w., bl. 8.

so) C. T. Onions (red.). The Shorter Oxford English Dictionary, Oxford 1973. bl. 2192. 
van die biddende se geloof afhang. Terwyl die Remonstrante egter slegs stel dat God rekening hou met die geloof van die uitverkorene, trek Visser 't Hooft God in die geloof van die "Christen" in. God word inderdaad 'n transendentele projeksie van die mens, die "superhuman". As Visser 't Hooft werklik die Barthiaan was wat hy voorgee om te wees $^{61}$ ), sou hierdie eienaardige uitsprake onmoontlik wees.

Visser 't Hooft maak egter self ook sy stelling oor défaitisme tot niet. Sy implisiete gebruik van I Kor. 15:58 toon 'n ernstige verenging van die boodskap van dié teksvers. Alreeds vers $\mathbf{5 7}$ dui aan hoe vers 58 verstaan moet word, naamlik Christologies. Vanuit die sterwe en die opstanding van Jesus Christus waar die sondaarmens waarlik geregverdig is en ware vrede met God ontvang, sal die arbeid in die Heer nie tevergeefs wees nie. Eers as die regverdiging in Jesus Christus geskied het en die vrede tussen God en mens daargestel is, kan daar van arbeid in die Heer sprake wees. Hierdie arbeid is dan die betuiging van dankbaarheid en kom duidelik te voorskyn in die roeping van die gelowige. Daar kan dus nie gewerk word om geregtigheid en vrede soos wat Visser 't Hooft dit stel nie, al noem hy dit ook ,arbeid in die Heer". Hierdie uitlegging van Visser 't Hooft dui duidelik daarop dat sy gedagtes uitgaan van die selfstandigheid van die inherente goeie mens.

Teenoor 'n Marxis wat sê dat die eindigheid van die mens in die welsynstaat begin en J. P. Sartre wat sê dat eers sosiale verbetering moet intree en dan is daar plek vir die etiek, stel $V$ isser 't Hooft dat die opstand van die gepeupel ' $n$ stryd om waardigheid en vryheid is, sowel as om materiële verbetering. Visser ' $t$ Hooft betree nou die gebied van die filosofie. Sy stelling word dan ook feitlik in alle sosiaal-rewolusionêre teorië teruggevind. Selfs vir Karl Marx het dit gegaan om die daarstelling van ' $n$..menswaardige" lewe.$^{62}$ ) Menswaardigheid en 'n sodanige vryheid sluit aan by die selfstandige mens van Visser 't Hooft.

Dat sonde vir Visser 't Hooft 'n slegte eienskap is wat met kraginspanning oorwin kan word, word duidelik as hy sê: „Just as he knows that the battle against $\sin$ in his own life is not hopeless, so he continues to fight against social sin." Daar is dus geen sprake daarvan dat die mens volslae sondaar is nie. Hierdie Pelagiaanse standpunt wat die mens onder die magtige invloed van die longus usus peccandi stel en die wilsvryheid

61) W. A. Visser 't Hooft, a.w., bl. 19.

62) H. de Vos, a.w., bl. 116. 
handhaaf, ${ }^{63}$ ) stel Visser 't Hooft in staat om die mens sy selfstandige besluit te laat neem en so dus te laat werk vir ,geregtigheid" en "vrede". Die oorwinning van Christus wat hy vermeld, dien vir die mens slegs tot navolgenswaardige voorbeeld.

Hierdie standpunt word in die geskiedenis van die ekumeniese beweging teruggevind waar in die boodskap van die Oxfordvergadering in 1937 van Life and Work die volgende voorkom:

.The forces of evil against which Christians have to contend are found not only in the hearts of men as individuals, but have entered into and effected the structure of society, and there also must be combated." ${ }^{\prime 4}$ )

7.1 Vir Christene is die norm vir sosiale en politieke aksie nie die sukses van enige sisteem, enige party, enige nasionale of rasseof selfs religieuse groep nie maar die gemeenskaplike welsyn. Die vraag is of hiérdie of dáárdie besluit of aksie die mense sal help of hinder om hulle menslike roeping te vervul.

7.2 As dit nog nie duidelik was nie dat die sosiale etiek van Visser 't Hooft geensins in verbinding staan met die belydenis van die kerk nie, dan sê hy dit met hierdie sewende stelling. Die gemeenskaplike welsyn wat norm moet wees vir die Christen se handeling staan dus in die plek van die enigste norm vir die handeling van die gelowige, naamlik die Woord van God. So 'n gemeenskaplike welsyn vind sy wortels in 'n geregtigheid wat dus buite Christus om as moontlik geag woró.

Dit word gevind in die inherente goeie mens. Die reg waarvolgens sodanige welsyn kan bestaan, is die natuurreg. Aangesien hierdie norm in die plek van die Woord van God te staan kom, relativeer dit die Woord tot ' $n$ minderbeduidende grootheid, wat wel in diens van die norm gebruik mag word. Dit beteken dat hier van ' $n$ ideologie sprake is. Kortom, hier kom die „superhuman" weer ter sprake.

In hierdie sin moet ook sy uiteensetting gesien word dat ' $n$ Christen nie sy teenstander ten volle afskryf as die verpersoonliking van die bose nie. Dit kan ook nie, want as die mens inherent goed is, moet hy dus net gehelp word om die goeie te doen. Dit word gedoen deur hom te bevry van verhinderende faktore wat die vorm van sosiale strukture of 'n gebrek aan die ",regte" insog kan aanneem. Daarom is die berig aangaande

63) J. N. Bakhuizen van den Brink, Handboek der Kerkgeschiedenis, Den Haag 1965, DI. I, bl. 260.

64) J. W. Turnbull, a.w., bl. 49. 
die „Freedom Movement” vir hom 'n sprekende bewys. Die "Freedom Movement" was egter meer filosofies georiënteer as godsdienstig en verder ' $n$ duidelike politieke beweging. ${ }^{65}$ )

Hierdie hele standpunt van Visser 't Hooft word gevind in die ekumeniese teologie soos byvoorbeeld in die hoofberig oor kerk, gemeenskap en staat in verhouding met die ekonomiese orde van Life and Work by die Oxford-vergadeirng in 1937:

„Christianity, however, recognizes that the image of God in man is so defaced by sin that man's native worth and dignity is largely obscured." ${ }^{.66}$ )

Visser 't Hooft kom nou terug tot die kerk as hy sê dat die kerk as versoende gemeenskap dié versoening oor alle verskille wat die mensdom skei moet manifesteer. Dit word nou 'n vraag wat hy met „versoende gemeenskap" sou bedoel. Gesien in die lig van die voorafgaande, kan nie anders geantwoord word nie, as dat dit ' $n$ gemeenskap is wat onderling versoen is nie. Aangesien hy nie expressis verbis die dood van Christus met die regverdiging van die sondaar en die versoening van die mens met God in verband bring nie, moet sy verwysing daarna beskou word as die verwysing na 'n navolgenswaardige voorbeeld. Daarom word versoening van rasse aan die kerk opgedra as die essensie van die evangelie wat in hulle lewe gerealiseer moet word. Juis daarom kan hy die geloofwaardigheid van die evangelie aan rasse-skeiding of -vermenging knoop. Dat hierdie standpunt ook in die ekumeniese teologie terug te vind is, vind ons in ' $n$ verklaring van die Sentrale Komitee van die Wêreldraad van Kerke oor rasse- en etniese spanning ten tyde van 'n vergadering van dié komitee te Rochester, New York in 1963. Hulle sê onder andere:

.The first requirement for the churches in respect of race is that they themselves remove racial barriers in their own fellowship. Only thus can their claim to work for justice, human dignity and brotherhood be made credible." ${ }^{.67}$ )

Soortgelyk is die besluit van die algemene vergadering van die Wêreldraad van Kerke te Evanston in 1954. ${ }^{\mathrm{c}}$ ) Visser 't Hooft stel dit dan ook dat dit die belangrikheid van die ekumeniese beweging is, naamlik om die versoenende krag van die kruis te manifesteer. Ons het reeds gesien dat dit hier vir hom slegs gaan om ' $n$ navolging van Christus.

05) M. Teodori (red.), The New Left, London 1970, bl. 93 vv.

(is) J. W. Turnbull, a.w., bl. 56.

6i) Ecumenical Statements on Race Relations, Genève 1965, bl. 37. Voortaan word hierna verwys as Statements. 
8.1 Aangesien God met alle mense as verantwoordelike wesens handel, tree die Christen in vir 'n gemeenskap waarin alle verhoudinge deur verantwoordelikheid beheers word. Die staat is verantwoordelik aan die burgers en dit wat die staat transendeer. Die burgers is verantwoordelik vir die welsyn van die medeburgers en vir die algemene lewe in die maatskappy.

8.2 Die ontwerp oor die aard van 'n staat wat Visser ' $t$ Hooft hier gee, is die ontwerp wat gegee word in die "Responsible Society": 'n begrip wat deur die eerste algemene vergadering van die Wêreldraad van Kerke in 1948 te Amsterdam ontwikkel is.

,A responsible society is one where freedom is the freedom of men who acknowledge responsibility to justice and public order, and where those who hold political authority or economic power are responsible for its exercise to God and the people whose welfare is affected by it." ${ }^{\circ}$ )

Visser ' $t$ Hooft het self gehelp om hierdie begrip te formuleer en dit was bedoel om 'n alternatief daar te stel vir die twee uiterstes, naamlik kommunisme en laissez-faire-kapitalisme. "i) Hierdie gemeenskap kan as 'n demokratiese sosialisme beskryf word.

Dit word duidelik in die eerste paragraaf van die uitvoering waar Visser 't Hooft die Christelike geloof stel as 'n suurdeeg wat die sogenaamde outoritêre (kapitalistiese) en kollektiwistiese (kommunistiese) gemeenskappe verander in 'n gemeenskap verander in 'n gemeenskap waar alle mense verantwoordelik is vir die gemeenskapslewe. Hierdie demokratiese sosialisme sal 'n humanitêre gesig dra, aangesien die mense daarin nie nommers nie, maar persone sal wees.

Die tweede paragraaf stel die uiteindelike verantwoordelikheid van die mens aan God. Dit impliseer die relatiwiteit van die staat ten opsigte van God en die regbank. Wat egter opval, is die herhaling van "norms which transcend the state". Daar bestaan dus sekere beginsels waaraan die staat gehoorsaam moet wees. Dat dit nie God en sy Gebod is nie, word duidelik uit die feit dat God in die hele betoog die Een is aan wie verantwoording verskuldig is en nie die een wat die norme vir die aksie van die staat neerlê nie. Wat Visser 't Hooft presies bedoel, moet sekerlik in die rigting van die natuurreg gesoek word. Wanneer Visser 't Hooft in die volgende paragraaf op grond van die Cottesloe-beraad van 1960 wil beweer dat meer

iii) H. E. Fey (red.) The Ecumenical Advance, London 1970, bl. 241.

68) Statements, bl. 22.

69) J. W. Turnbull, a.w., bl. 130 
as $80 \%$ van die kerke van Suid-Afrika vir politieke integrasie gestem het, moet daarop gewys word dat dit geensins 'n stemming was wat verteenwoordigend van die kerke was nie, aangesien die deelnemers as individue aan die stemming deelgeneem het. ${ }^{i 1}$ ) Uiteraard kan ' $n$ konferensie in teenstelling met 'n kongres geen verteenwoordigende besluit neem nie. Dit word ook bevestig deur die samestelling van die Cottesloeberaad, waar alle kerke, ongeag hulle lidmatetal, tussen 5 en 10 verteenwoordigers kon stuur. ${ }^{72}$ ) Om op die Cottesloe-beraad dus 'n standpunt te bou wat inhou dat (hier word Suid-Afrika duidelik geimpliseer) die enigste Christelike weg vir Suid-Afrika die weg van ,one man, one vote" kan wees, is dus nie moontlik nie. Die grond vir so 'n standpunt is eerder by die ekumeniese beweging te vind, byvoorbeeld by die stigtingsvergadering van die Wêreldraad van Kerke in 1948 te Amsterdam waar die volgende verdoeming uitgespreek word:

„We therefore condemn:

2. Any denial to man of an opportunity to participate in the shaping of society, for this is a duty implied in man's responsibility towards his neighbour." ${ }^{\text {;3) }}$

Hieruit word die stelling ook duidelik dat die burger sy broeder se hoeder is. Dit is inderdaad die ideaal van die demokratiese sosialisme met die menslike gesig.

9. Die negende stelling is uitgelaat, dit wil sê indien daar nie ' $n$ fout by die numering gekom het nie.

10.1 Christene moet alle gebruik van mag op geestelike gebied repudieer, maar besef dat dit op sosiale gebied onvermydelik en nodig is. Dit gaan dus nie daarom óf mag gebruik moet word nie, maar wel hóé dit gebruik moet word.

10.2 Hierdie stelling gebruik Visser ' $t$ Hooft om by sy bewering uit te kom dat die demokrasie die regeringsvorm is wat die minste gevaar inhou, aangesien daar sekere kontrol-momente in voorkom. Sy verstaan van die demokrasie sluit aan by sy beeld van die mens, naamlik dat die strukture van die lewensomgewing van die mens bepalend is vir die moontlikheid van die mens tot 'n eties goeie handeling. Hoewel hy oënskynlik sê dat die mens nie goed is nie, sê hy tog in dieselfde sin dat die mens net nie goed genóég is nie. Daarom is die demokrasie die beste regeringsvorm. Mag moet dus op 'n verantwoordelike wyse (veral verantwoordelikheid aan die mens) uitgeoefen word.

i1) L. A. Hewson (red.), Cottesloe Consultation, Johannesburg 1961, bl. 91.

i2) L. A. Hewson, a.w., bl. 89.

г3) J. W. Turnbuli, a.w., bl. 131. 
Die demokrasie stel die beste moontlikheid daar vir die individu om deel te kan hê aan die uitoefening van mag. Hierdie beginsel stel Visser 't Hooft om die verantwoordelikheid en plig van die individu te beklemtoon waarop hy later weer terugkom. Dit is duidelik dat hy besig is om in sy besinning oor die staat telkens weer sulke momente na vore te bring wat daarop gerig is om totalitarisme teen te gaan. Dit doen hy nie sonder betekenis nie, want reeds onder 8.2 het ons gesien dat die tendens van sy toespraak ' $n$ politieke integrasie van alle rasse-groepe inhou, ' $n$ tendens wat op eenrassige totalitarisme sinspeel. Daarom stel hy dat daar nie net twee magsfaktore, naamlik regering en rykdom is nie, maar met ' $n$ desentralisasie van mag wil hy op 'n duidelike wyse die indiwidu by die uitoefening daarvan betrek.

11.1 Die Christelike kerk is uiteraard verplig om vir armes en onderdruktes en teen uitbuiting en tirannie standpunt in te neem.

11.2 Wat Visser 't Hooft met hierdie stelling beoog is om die evangelie in diens te stel van 'n sosiale hervormingsplan. Hy baseer sy stelling op die gedeeltes in die Bybel wat deur die sosiaalrewolusionêre rigtings gebruik word om te bewys dat die kerk inderdaad ' $n$ horisontale funksie te vervul het (Amos en die Magnificat van Maria). Wat hier gebeur, is dat die diens van die barmhartigheid van die kerk wat uit naasteliefde geskied en ook moet geskied, en dit wel uit dankbaarheid tot eer van God, vervang word met ' $n$ vermeende plig tot geregtigheid. Dit kom daarop neer dat die armes nie met barmhartigheid geholpe is nie, maar met sg. sosiale geregtigheid. Dit is duidelik dat hierin 'n aktiwistiese strekking skuil.

Dat daar geen grond is in die stelling van Visser ' $t$ Hooft nie, word duidelik uit die feit dat Amos 8 nie sonder Amos 4 gelees kan word nie. ${ }^{i t}$ ) Wat die Magnificat betref, is dit duidelik dat die betekenis daarvan eskatologies is. ${ }^{75}$ ) Daarom kan dit nie gebruik word om in diens gestel te word van sosiaal-rewolusionêre strewes nie. Visser 't Hooft sien egter daarin die bevestiging dat die wese van die Christelike boodskap sosiaal van aard is.

Sy poging om Johannes Calvyn na aanleiding van sy kommentaar op Habakuk 2:6 as ' $n$ vader van die rewolusionêre gedagte te klassifiseer, is sonder enige grond. In sy kommentaar op Hab. 2:6 verklaar Calvyn die woorde "Hoe lank nog" as "

74) J. van der Graaf (samesteller), Het Getuigenis, Kampen 1973, bl. 12.

ii) K. H. Rengstorf, Das Evangelium nach Lukas, gepubliseer in Das Neue Testament Deutsch, Göttingen 1969, Bd. 3, bl. 31. 
roepstem tot God. God self het die roep in die hart van die mens geplaas omdat $\mathrm{Hy}$ self die Verlosser en Wreker is, omdat $\mathrm{Hy}$ self hierdie roepstem wil hoor. ${ }^{76}$ )

Hierdie poging om die kerk in diens te stel van sosiaal-rewolusionêre programme is alreeds te vind in die ekumeniese teologie soos wat dit te Nieu-Delhi in 1961 geformuleer is:

„Where oppression, discrimination and segretation exist, the churches should identify themselves with the oppressed race in its struggle to achieve justice." ${ }^{\prime 77}$ )

Die oorsprong van Visser 't Hooft se sosiale evangelie moet by die ekumeniese beweging gesoek word, asook by sy beeld van die selfstandige mens, eerder as dat dit gronde sou hê in die Bybels-reformatoriese teologie.

12.1 Aangesien Christene intree vir geregtigheid en vir die vrye uitoefening van verantwoordelikheid deur alle mense, is hulle geroep om ongeregtigheid en onderdrukking teen te staan. Wanneer ongeregtigheid en onderdrukking geïnstitusionaliseer is in politieke- en sosiale sisteme, mag hierdie teenstand verplig wees om die vorm van teenstand teen die owerhede in te neem.

12.2 Met die oog op hierdie stelling het Visser 't Hooft tot dusver geteologiseer. Sy betoog tot dusver was dus om ' $n$ teologiese basis aan ' $n$ reg van opstand te verskaf. Wanneer hy dan die owerheid as instrument van God ten dienste van die mens stel, word dit duidelik dat die mens weer die sentrum van sy denke vorm. Die taak van die owerheid is hier om toe te sien dat die welsyn van die mens gedien word. Ons het reeds onder 7.2 gesien dat hierdie welsyn ingerig word volgens die natuurreg. As sodanig is die geregtigheid wat moet geld, geen geloofsgeregtigheid nie.

Met hierdie stelling vind Visser ' $t$ Hooft by Luther slegs gedeeltelike ansluiting en by Calvyn geen. Wat Luther betref, regeer die owerheid wel volgens die natuurreg. ${ }^{78}$ ) Visser ' $t$ Hooft verskil van hom egter in dié sin dat hy meen dat daar tóg met behulp van die evangelie op die wêreld regeer moet word. in Sodanige regering geskied egter volgens natuurregtelike norme, aangesien die inherente goedheid van die mens die natuurreg sanksioneer.

70) John Calvin, Commentaries on the Twelve Minor Prophets, Michigan 1950, Vol. 4, bl. 93 vv.

77) Statements, bl. 30.

is) C. J. Mans, a.w., bl. 94. 
Wat Calvyn betref, is dit duidelik dat Visser 't Hooft geen aansluiting het nie, al probeer hy ook om Calvyn vir sy stellings in te span.

.In concretu kom Calvyn se siening op die volgende neer: Die owerheid het 'n wêreldlike taak en tog is dit nie sy eintlike taak om te sorg vir die liggaamlike welsyn van sy onderdane nie, alhoewel dit ook by sy taak ingesluit is. Sy eintlike roeping is om toe te sien, dat daar onder die christene in openbare gestalte van die Godsdiens sal wees en dat daar onder die mense humaniteit sal bestaan "."79)

Hieruit word duidelik dat die owerheid nie primêr in diens van die mens staan nie, maar daargestel is tot eer van God. Daar bestaan dus by Calvyn geen natuurregtelike basis vir die owerheid nie. Vir Calvyn het die natuurreg onder die oordeel van die sondeval gestaan en „het hy nooit op grond van die ,natuurlike reg' en die aangebore, onvervreembare menseregte 'n politieke program gebou nie, veral nie 'n program van rebellie as gevolg van die oortreding van die ,natuurlike reg' nie". ${ }^{\text {80 }}$ )

Visser 't Hooft se mistasting in verband met Calvyn word verder baie duidelik wanneer hy sê dat die "laere magistrate" waarvan Calvyn praat, gekies is om die volk te verteenwoordig. Die amp van volksmagistraat sien Calvyn ook as ' $n$ instelling van God wat volgens God se ordinansie die volk moet beskerm. ${ }^{81}$ )

Die steun wat hy meen by John Knox te vind, bewys duidelik die natuurregtelike oorsprong van sy etiek. ${ }^{82}$ ) Dat die Skotse Belydenis van 1560 die deure oopmaak vir sosiale revolusie moet saam met $P$. Jacobs as versinsel afgewys word. ${ }^{83}$ )

Visser 't Hooft meen egter om met die vermelding van Calvyn, Knox en die Skotse Geloofsbelydenis in 'n goeie ortodokse tradisie te staan. Afgesien daarvan dat die teendeel bewys is, kanselleer Visser 't Hooft hierdie mening self as hy sê dat teenstand alleen geregverdig kan word indien dit die buurman uit sy nood help. Soos ons reeds gesien het onder 7.2 lê so 'n regverdiging buite Christus. Dit relativeer dan ook die norm om onskuldige bloedvergieting te voorkom.

io) C. J. Mans, a.w., bl. 96.

so) B. J. Engelbrecht, Die Leer van John Knox oor die Reg van Opstand teen die Burgerlike Owerheid, artikel in Die Hervormer, Krugersdorp 1960, Jrg. 51, no. 2, bl. 27.

81) J. Calvyn, Institutio Christianae Religionis, gepubliseer in O.S. V. 501 , 16 vv.; IV, xx, 31.

82) B. J. Engelbrecht, a.w., bl. 28.

83) P. Jacobs, Theologie Reformierter Bekenntnisschriften, Neukirchen Kreis Moers 1959, bl. 131-132. 
Dat die gebeure rondom die 20ste Julie 1944 in Duitsland as voorbeeld gebruik kan word, is onwaarskynlik aangesien dit duidelik is dat daar meer motiewe teenwoordig was as bloot Christelike.$^{84}$ )

Nadat Visser 't Hooft ' $n$ vermeende teologiese basis opgestel het vir ' $n$ reg van opstand teen die owerheid, bly eintlik nog net die taak oor om praktiese implikasie daaraan te verleen. Hy noem vier maniere van verset.

Die eerste vorm is geestelike verset. Dit dra Visser ' $t$ Hooft aan die kerk op. Deur die verset in onder andere die liturgie van die kerk in te bring, vind ' $n$ aanmerklike verenging plaas van die profetiese taak van die kerk, aangesien dit duidelik is dat hy hiermee slegs ' $n$ eensydige partyskap ter wille van die sogenaamde uitgebuites en onderdruktes bedoel. Dit is verder opmerklik dat hy hierdie taak aan minderheidsgroepe in die kerk opdra, indien die kerk passief sou bly. Dit versterk die gedagte van partyskappe in die kerk en kan in die lig van sy betoog alleen op negatiewe kritiek dui. „Die profetiese taak van die kerk sluit nie kritiek uit nie, maar in. ${ }^{85}$ ) Die kritiek van die kerk het die Woord van God as uitgangspunt en norm.

"Die Kerk kan nie saam huil met die wolwe in die bos nie, al is hulle ook humane wolwe! Hy kan geen beter uitgangspunt en norm begeer nie, want God se Woord is self kritiek: God se kritiek oor al die woorde en werke van kerk, volk en owerheid." ${ }^{86}$ )

Onafskeidelik verbonde aan die profetiese taak van die kerk is die apostoliese. Die profeties-apostoliese taak moet die kerk as kerk uitoefen. Almal staan dan onder hierdie verkondiging van die Woord; owerheid sowel as onderdaan. Niemand word uitgesluit nie en geen partyskappe verwek nie. Die taak van die kerk is dus nie net kritiek nie, maar ook voorligting. ${ }^{8 i}$ )

So ook moet die gebed van die kerk nie téén die owerheid wees nie, maar vir die owerheid (I Tim. 2:1-4), want daardeur word die welsyn van die mense gedien en die voortgang van die evangelie verseker ${ }^{88}$ )

84) F. Zipfel, Gedenkstätte Plötzensee, Berlyn 1972, bl. 23. Vgl. ook H. H. Esser, Demokratie und Kirche, artikel in Zeitschrift für Religionspädagogik, Dortmund 1971, Jrg. 26/10 bl. 333.

85) C. J. Mans, a.w., bl. 112.

88) C. J. Mans, a.w., bl. 113-114.

8i) C. J. Mans, a.w., bl. 109 vv.

88) C. J. Mans, a.w., bl. 114. 
Visser 't Hooft wil met hierdie standpunt 'n humane element in die rewolusie indra, wanneer hy die kerk as wagter aanstel. Dit is ' $n$ gedagte wat by die Algemene Vergadering van die Wêreldraad van Kerke te Nieu-Delhi ontstaan het as 'n metode van aksie:

,Where oppression, discrimination and segregation exist, the churches should identify themselves with the oppressed race in its struggle to achieve justice. Christians should be ready to lead in this struggle. The revolution is taking place whether we recognize it or not, and without Christian leadership it may be tragically perverted." ${ }^{\prime 89}$ )

Die tweede vorm van verset is wettige politieke opposisie. As vorm van verset kan dit uiteraard nie geld nie en is die verwysing daarna onnodig.

Die derde vorm van verset is onwettige metodes indien wettige opposisie onmoontlik geword het. Die norm wat Visser ' $t$ Hooft vir hierdie handeling aanlê, is of die wette soos wat die uitgevoer moet word, die welsyn van die mens dien en of dit eerder gevestigde „ongeregtigheid" impliseer. Die belangrike moment is dus weer geregtigheid. Visser 't Hooft maak implisiet 'n skeiding tussen lex en jus. Soos ons gesien het, ressorteer geregtigheid by Visser 't Hooft onder die natuurreg. Jus is daarvolgens, jus naturale. Lex, wat uiteraard lex naturalis is, kan dus gerelativeer word. Die Reformatore, daarenteen, het o.I.v. Calvyn uitgegaan van die standpunt dat jus, jus divinum is en het geen skeiding gemaak tussen jus en lex nie. Gevolglik het hulle die soewereiniteit van die wet gehandhaaf. ${ }^{90}$ )

Wetsoortreding was daarom ongeoorloof. Jus naturale het volgens Calvyn onder die sondeval geressorteer. In beide gevalle sou Visser 't Hooft se standpunt volgens die Bybelsreformatoriese teologie dus veroordeeld gestaan het. In die lig hiervan kan die argument dat dit 'n ultima ratio is, geen krag hê nie. Net so het die lyding onder die gevolge waarvan hy praat, geen verdienste nie (Ps. 127:1!).

Die vierde en laaste vorm is gewelddadige verset. Weer probeer Visser 't Hooft aansluiting soek by Calvyn met die vermelding van laasgenoemde se manifesti vindices. Die verbinding tussen hierdie openbare wrekers en die mense wat deel gehad het aan die gebeure van 20 Julie 1944 in Duitsland moet saam met H. H. Esser bevraagteken word. ${ }^{01}$ ) Hierdie poging dui egter

89) Statements, bl. 30.

so) A. H. Murray. The Vindicae contra tyrannos, in Acta Juridica, Kaapstad 1966, bl. 301-302.

91) H. H. Esser, a.w., bl. 333. 
duidelik daarop dat Visser 't Hooft geen aansluiting by die Bybels-reformatoriese teologie kan vind nie. Dit word verder duidelik wanneer hy geweldadige verset as ' $n$ ultima ratio beskou in die diens van geregtigheid. Soos reeds telkemale gesien, kom geregtigheid by hom voort uit natuurregtelike oorwegings en as sulks is ' $n$ beroep op Calvyn geheel en al ongegrond. Die openbare wrekers waarvan Calvyn praat, tree alleen op deur 'n legitima Dei vocatio wat baie ver van alle natuurreg verwyder is.

„In jedem Falle hat das göttliche Recht den Vorrang, und Volkssouveränität o.ä. sind dabei ausgeschaltet, damit auch die ganze Breite einer naturrechtlichen Begründung des Widerstandsrechtes. ${ }^{\text {"92 }}$ )

Die standpunt van Visser 't Hooft wat uit die natuurreg verkry is en as sulks onder sondeval ressorteer, is dus onaanvaarbaar vir 'n kerk wat op Calvinistiese belydenisgrondslag staan en vir wie daar gevolglik geen ander geregtigheid as geloofsgeregtigheid kan bestaan nie. Dit gaan dus om die regte interpretasie van Rom. 13:1-7.

Daar is vir Visser 't Hooft slegs 'n graadverskil tussen gewelddadige en geweldlose verset. Dit beteken dus dat die kwalitatiewe element uitgeskakel is. In hierdie geval word nie vanuit 'n beginsel gewerk nie, maar is gewelddadige verset ' $n$ pragmatiese oorweging; die doel heilig die middele.

Die waarskuwings wat Visser 't Hooft nou uitspreek, nadat hy meen om ' $n$ teologiese basis aan gewelddadige verset te gegee het, moet as demagogie beskou word.

Wanneer hy oor polisie-toesig praat, word dit duidelik dat hy op Suid-Afrika dui, aangesien dit 'n spook is wat by die Wêreldraad van Kerke die verbeelding wakker hou. Die ondergrondse propagandametodes wat hy aanbeveel, moet op dieselfde vlak as die subversiewe werking van die marxisme beskou word. Dit is temeer so, aangesien binne Suid-Afrika nog altyd persvryheid bestaan het.

Vir die tweede keer praat hy van die gepeupel, (vgl. 6). Die "preparation of the masses for a new day" herinner sterk aan die taal van Karl Marx:

.... il doit, pour employer les mots de Marx, expliquer aux masses leur propre action non seulement afin d'assurer la continuité des expériences révolutionaires du prolétariat, mais aussi d'activer

92) H. H. Esser, a.w., bl. 332-333. 
consciemment le développement ultérieur de ces expériences. ${ }^{.83}$ )

Nadat Visser 't Hooft tot dusver inderdaad verset as 'n Christelike reg en plig daargestel het, verbaas dit enigsins dat hy sê dat niemand, wat nie self binne die konkrete situasie verkeer waarin ' $n$ besluit geneem moet word nie, aan diegene wat daarbinne is, kan sê wat hulle plig is nie. Hierdeur probeer hy dus die indruk wek dat hy sy hande in onskuld was. Die vloeibaarheid in sy betoog aangaande Christelike optrede, is ' $n$ bewys daarvan dat daar by hom inderdaad die verwarring bestaan wat in sy inleiding genoem is. Soos ons gesien het, het hierdie verwarring sy oorsprong in ' $n$ vrysinnigheid ten opsigte van die kerk se belydenis.

13.1 Alle mense moet tussen twee wêreldbeskouinge kies; enersyds dat die beskawing van die wit ras ten alle koste gehandhaaf word, andersyds dat ' $n$ veelrassige internasionale gemeenskap ontstaan.

13.2 Die ekumeniese beweging het die tweede moontlikheid gekies en sien dit as die wil van God.

Visser ' $t$ Hooft grond sy stelling op die mening van die Life and Workkonferensie in 1937 te Oxford soos dit te vind is in die verslag van Oldham. ${ }^{94}$ ) Hieruit word duidelik dat in die plek van die Corpus Christianum ' $n$ Societas Oecumenica moet tree. 'n Sienswyse waarin die afsonderlikheid van rasse gehandhaaf word, vorm 'n ernstige strategiese belemmering vir die bereiking van hierdie sekulêre ideaal. Die ou verbinding van troon en altaar vind sy analogie in die nuwe veelrassige wêreldgemeenskap waarvan Visser 't Hooft praat; ' $n$ wêreldkerk vir 'n wêreldstaat. Die verskil tussen die twee ideale lê daarin dat by laasgenoemde die inisiatief van die wêreldstaat uitgaan en die wêreldkerk dus 'n moraal moet voorsien vir die instandhouding van die wêreldstaat. Dit is duidelik die ekumeniese strewe in teenstelling met dit wat in 1950 te Toronto verklaar is. ${ }^{95}$ ) In hierdie verband moet dan die aangekondigde stryd van die ekumeniese beweging teenoor alle vorme van rasseskeiding gesien word soos dit deurgaans in verklarings van die ekumeniese beweging te vind is. Visser 't Hooft se toespraak vorm daarom 'n onderdeel

93) G. Lukács, Lénine, Parys 1965, bl. 62. Aangehaal by P. Freire, Pedagogy of the oppressed. New York 1972, bl. 38. Dit is duidelik dat Visser 't Hooft hierdie spesifieke geskrifte, beide van Lukács en Freire, op daardie stadium nog nie kon gelees het nie. Die aanhaling dui egter op die wesenlike ooreenkoms in die gedagtegang van Visser ' $t$ Hooft met dié van die marxisme.

94) J. H. Oldham. Foundations of Ecumenical Social Thought, Philadelphia 1966, bl. 139-141.

s5) H. E. Fey, a.w., bl. 29-30. 
van hierdie stryd teen rasseskeiding en moet in die lig van die groot geheel gesien word, eerder as dat daaraan besondere teologiese waarde geheg word.

Deur hierdie sekularisering van die kerk word die eskatologiese wese daarvan ontken. Gevolglik word die binnewêreldse bestaan as die enig ware bestempel. Hierdie eindigheid ontvang 'n absolute karakter wat uiteraard 'n nuwe ideologie is en as die ekumenisme bekend staan.

14.1 Die kerke in lande met rasseprobleme is , in statu confessionis", dit wil sê hulle integriteit as verteenwoordigers van die nuwe mensheid en as draers van die goddelike woord van geregtigheid en versoening, hulle gehoorsaamheid aan hulle Heer, is op die spel.

14.2 In die lig van dit wat onder 13 gesê is, is dit alleen logies dat Visser ' $t$ Hooft rasse-integrasie tot belydenis verhef. Alle rasseskeiding moet dan ' $n$ ketterse oortreding word en moet as sodanig uitgegroei word. Geen ideologie waar die mens en sy wêreld as absolute gestel word, kan tot ' $n$ ander gevolgtrekking kom nie. Met hierdie standpunt staan Visser 't Hooft volledig in die ekumeniese tradisie soos wat dit byvoorbeeld in 1954 te Evanston geformuleer is:

„When we are given Christian insight the whole pattern of racial discrimination is seen as an unutterable offense against God, to be endured no longer, so that the very stones cry out."'96)

Hierdie belydenis moet konkrete uitvoering kry en ons sien dat Visser 't Hooft weer die aanvanklike onderskeiding tussen kerk en Christen tref. Die „Christen" moet weer doen wat die kerk nalaat en in hierdie geval moet groepe binne die kerk dan nou ter wille van die kerk optree. Daar is reeds gewys op die onskriftuurlikheid van hierdie saak en op die feit dat die belydenis van die gelowige slegs belydenis van die kerk kan wees, omdat die belydenis van die kerk direk verbonde en afhanklik is van die Heer van die kerk. Belydenis kan dus net geloofsbelydenis wees. Dit word hieruit dus baie duidelik wat Visser 't Hooft onder belydenis verstaan, naamlik eerder 'n tipe propaganda ter wille van die ekumeniese ideaal as 'n geloofsbelydenis wat leef uit die Woord van God, tot eer van God.

Die gedagte dat klein groepies moet optree en baie effektief is, vind Visser 't Hooft ook nêrens anders as in die ekumeniese beweging nie. Dit is 'n ou tradisie wat reeds in 1937 te Oxford voorgekom het en wat op sy beurt nêrens anders as by die marxisme gevind is nie:

ms) Statements, bl. 19. 
„Because some things cannot be changed without state action or international adjustment, the effective power of 'two or three' men of conviction, who make themselves into a Christian 'cell' must not be underestimated. ${ }^{n i}$ )

Dit is daarom ook nie verbasend dat die steun van kerke oor die hele wêreld aan hierdie groepies toegesê word nie. Hiermee word van 'n plaaslike saak ' $n$ internasionale aangeleentheid gemaak. Dit gebeur omdat die wêreldkerk van die ekumeniese beweging nie kan toesien dat daar êrens ' $n$ verhindering van sy ideaal mag voorkom nie. Die rassekwessie wat eintlik plaaslik van aard is, omdat dit gaan om die plaaslike probleme wat ondervind word op politieke en gemeenskaplike gebied, word in die internasionale arena ingedra, met ' $n$ beroep op die samebinding in Christus en die solidariteit van alle kerke. Die rasseprobleem van Suidelike-Afrika word tot wêreldprobleem verhef, met die doel om ' $n$ beregtiging te verkry vir die ekumeniese bemoeienis daarmee. Hierdie oortuiging word uitgespreek in in die boodskap van die algemene vergadering van die Wêreldraad van Kerke in 1961 te Nieu-Delhi aan die Christene in Suid-Afrika:

„Racial strife is a world problem and we stand behind the convictions on this matter expressed by the Evanston Assembly in 1954. Christians everywhere are involved in the struggle for the elimination of segregation or discrimination on the grounds of race or colour. ${ }^{\prime \prime 98}$ )

Visser ' $t$ Hooft verbind sy belydenis van die kerk ten opsigte van rassesake met die profetiese taak van die kerk. Hiermee spreek hy onteenseglik die Suid-Afrikaanse kerke aan. Die wat integrasie beoefen moet daarmee voortgaan en die ander moet daarmee begin. Een van die essensiële sake wat hy vir die profesie van die kerk aanbied verdien aandag. Die kerk moet politieke integrasie profeteer. Hy gebruik die term "nation". Hierdie standpunt hou nie rekening met die pluraliteit van lojaliteite ${ }^{99}$ ) wat bestaan tussen die verskillende rasse en volke in Suid-Afrika nie. Die ander sake wat hy aanhaal is reeds behandel. Dat hierdie belydend-profetiese taak van die kerk wat Visser 't Hooft verkondig, afgewys moet word, het reeds duidelik geword.

97) J. W. Turnbull, a.w., bl. 87.

88) Statements, bl. 35. Vergelyk in hierdie verband ook bls. 18, 39, 40.

90) Ongepubliseerde verhandeling van E. Kohl, Die Rassentrage Südafrikas und die Haltung der Kirchen. Kiel 1964, bl. 406. 
Dit is egter van belang om daarop te let dat hy hierdeur probeer om die kerke in Suid-Afrika in die rol van die ..Bekennende Kirche" uit die Hitler-tyd in Duitsland te forseer. Dit word duidelik uit sy verwysings na die ervarings in Europa waar die kerk ' $n$ ketterse ideologie of ' $n$ nie-Christelike of benede- Christelike mensbeskouing moes beveg. Verder maak hy weer hier die onderskeiding tussen die kerk en die Christen. Hy dra aan die kerk slegs sogenaamde geestelike verset op. Die kerk het dus nie deel aan gewelddadige verset nie. Hy laat egter die moontlikheid dat die kerk in sy geestelike verset onderdrukking van die staat mag ervaar en dat dit lydelik aanvaar moet word met ' $n$ indirekte verwysing na Joh. 15:18 vv. Dit dui duidelik daarop dat hy van die rassekwessie 'n belydenissaak maak. Hy impliseer ook hiermee dat die regerings van Suidelike Afrika en spesifiek Suid-Afrika, van tirannieke aard is. Die indirekte vergelyking met die Hitler-regime is onmiskenbaar. Die standpunt oor die lyding van die kerk het dan ook sy neerslag gevind in die ekumeniese teologie soos geformuleer te Evanston 1954:

\section{.If Christian obedience leads to suffering, that is part of the price. ${ }^{.100}$ )}

Wat Suid-Afrika betref, dien daarop gewys te word dat dit nie die staat was wat gesorg het vir die beleid van afsonderlike ontwikkeling nie, maar die kerk. ${ }^{101}$ )

„En ons wil dit weer eens beklemtoon: die kerk het só getuig en só geleef voor volk en owerheid owerheid omdat hy daarvan oortuig is dat hierdie samelewingspatroon die enigste wyse is waarin daar geregtigheid vir almal kan geskied." ${ }^{102}$ )

Die geregtigheid is by Mans niks anders as geloofsgeregtigheid nie en moet in teenstelling met die natuurregtelike geregtigheid van Visser 't Hooft aanvaar word. Daarom kan rasse-integrasie as belydenis nie aanvaar word in ' $n$ kerk wat bely dat Jesus Christus die Heer is nie.

Wanneer hy waarsku dat die kerk nie teen 'n spesifieke regering of staat mag optree nie, toon dit 'n eienaardige dubbelslagtigheid in sy denke wat deur sy blote optrede by die Mindoloberaad verder bewys word. In teorie moet die kerk nie gelyk wees aan ' $n$ politieke party nie, maar die praktyk loënstraf sy woorde. Dit was ook sy houding in die tyd van die Tweede Wêreldoorlog t.o.v. Duitsland. Hoewel hy sê dat die een volk nie verdoem en die ander geseën moet word nie, was dit tog duidelik dat hy ' $n$ anathema oor Hitler en die nasional-sosialisme

100) Statements, bl. 19.

101 C. J. Mans, a.w., bl. 110.

102 C. J. Mans, a.w., bl. 110. 
uitgespreek het. Vrede met Hitler het hy as die einde van Europa beskou ${ }^{\text {to3 }}$ ) en wat sy standpunt oor beskawing betref, kon hy selfs sê dat die ekumeniese beweging nie kon swyg nie in ' $n$ tydperk waarin beslissing geneem moes word waarvan lewe en dood van die kerk en die beskawing afgehang het. ${ }^{104}$ ) Teenoor die kerk wat net geestelike verset mag uitoefen, stel hy weer die optrede van die individuele Christen of groepe Christene wat oor die reg en selfs plig van gewelddadige verset persoonlik moet besluit. Dat hy die besluit aan die individuele Christen of die groep Christene oorlaat, dien wel daartoe dat nie gesê kan word dat hy expressis verbis gewelddadige verset aanbeveel het nie. In die lig van die feit dat hy in beginsel geen afkeur daaroor uitgespreek het nie, maar inteendeel die moontlikheid inderdaad daargestel het as een wat deur individuele Christene gevolg kan word, moet dus gesê word dat hy inderdaad die weg open vir gewelddadige verset. Dit word verder bevestig deur die feit dat hy slegs 'n graadverskil waarneem tussen geweldlose en gewelddadige verset (vgl. 12).

Op die metode wat Visser 't Hooft aangee wat die Christen moet volg wanneer hy moet besluit oor geweldlose of gewelddadige verset hoef hier nie ingegaan te word nie, aangesien die opinievorming dieselfde is as dit wat deur die hele toespraak aangetref word; gewelddadige verset is as ultima ratio op natuurregtelike gronde moontlik. Dit is egter belangrik om daarom te let dat hierdie moontlikheid gestel word in 'n situasie waar die meerderheid van die mense, blank sowel as nie-blank, gelowiges is wat belydende lidmate van hulle onderskeie kerke is. Enige gewelddadige optrede ter wille van rasse-integrasie of ander sosiaal-politieke oogmerke het dus net die één betekenis, naamlik dat die rebelle-swaard magtiger ge-ag word as die skeppingsmagtige Woord van God.

Die beklemtoning van die persoonlike verantwoordelikheid as laaste woord, moet beskou word as 'n oproep tot die deurvoering van die beginsels wat tot dusver gestel is en as sulks geld dit as magtiging tot gewapende verset.

\section{Die invloed van die toespraak}

Die invloed van die toespraak op die beraad was nie gering nie. Hierdie invloed het sy neerslag gevind in die verslag van die groep wat gehandel het oor „Justice in the Political Life in Southern Africa". Tesame met argumente uit die toespraak van Z. K. Mat-

103) W. A. Visser 't Hooft, a.w., bl. 108.

104) W. A. Visser 't Hooft, a.w., bl. 112. 
thews is die meeste argumente van Visser 't Hooft in dié verslag opgeneem. ${ }^{105}$ )

Wat verdere uitwerking betref, is dit belangrik dat W. H. Crane wat die Bybelstudie vir die Mindolo-beraad hanteer het, na die moord op Eduardo Mondlane kon sê:

"Was er und seine Genossen der FRELIMO damals brauchten, waren nicht Predigten über Gewaltlosigkeit anstelle der Gewalt, sondern die Hilfe der christlichen Gemeinde beim Lernen dessen, wie man Gewalt anwendet ohne Menschenhass, mit einem Maximum an Beherrschung und Disziplin und mit dem klaren Ziel der Errichtung einer nichtrassistischen Gesellschaft die allen Menschen Gerechtigkeit und Menschenwürde garantiert." ${ }^{106}$ )

\section{Gevolgtrekking}

Die Mindolo-beraad het plaasgevind in ' $n$ tydperk waarin politieke vloeibaarheid die situasie gekenmerk het. Tesame met die Wêreldraad van Kerke het internasionale magspolitiek ' $n$ belang by die beraad gehad. In hierdie opset moes Visser 't Hooft 'n teologiese basis vir gewapende verset verskaf, iets wat in elk geval sou plaasvind. Daarom wek die geheimhouding rondom die beraad die indruk van 'n sameswering.

Visser 't Hooft se sosiale etiek is geen Christelike etiek in Bybels-reformatoriese sin nie. Sy teologie is nie gebonde aan ' $n$ spesifieke Bybels-reformatoriese belydenis nie en toon subjektiewe relatiwisme, mede ten gevolge daarvan dat daar by hom onsekerheid in verband met die christologie bestaan.

Hy leer 'n Christenheid los van die kerk en daar ontbreek 'n eskatologiese binding in sy teologie. So dink hy Pelagiaans oor die sonde wat die gevolg het dat sy etiek op natuurregtelike beginsels berus. Die Heilige Gees is ook geen faktor in sy teologie nie en so kan die mens selfstandige etiese besluite neem; die mens kan die wil van God selfstandig leer ken.

Visser 't Hooft maak van die evangelie ' $n$ Wet wat sy aktiwistiese oortuiging aandui en hom in die nabyheid van die "Schwärmer" bring. So is die koninkryk van God vir hom 'n binnewêreldse grootheid wat deur die inherente goeie mens realiseerbaar is. God word dan gebruik om die besluite van die mens te sanksioneer.

Geregtigheid is by Visser 't Hooft geen geloofsgeregtigheid nie en gevolglik is versoening slegs tussen mens en mens en nie soseer tussen God en mens te verstaan nie. Daarom kan hy rassevermenging tot die wese van evangelie reken.

10i.) W. A. Visser 't Hooft, Memoires, Amsterdam 1971, bl. 262.

נrki) W. H. Crane aangehaal. by C. Ordnung. Eduardo Mondlane, Berlyn 1971. bl. 32 . 
Hy leer 'n navolging van Christus wat op staatkundige vlak uitmond in 'n demokratiese sosialisme met 'n menslike gesig. Die evangelie word dus in diens gestel van 'n wêreldverbeteringsprogram: die kerk kry bloot 'n horisontale funksie.

Visser 't Hooft het geen aansluiting by Calvyn nie, aangesien sy etiek en staatsbegrip op natuurregtelike beginsels berus. Daarom is onwettige optrede asook gewapende verset wat hy beide as ultima ratio stel, onaanvaarbaar vir 'n kerk met gereformeerde (Calvinistiese) belydenis. Al sou daar ook 'n teologiese basis bestaan het vir sy leer oor die reg van opstand, is dit nogtans nie toepasbaar op Suidelike Afrika nie.

Sy denkpatroon ten opsigte van klasseverskille toon ooreenkoms met dié van die marxisme. Sootrgelyk is sy idee in verband met klein groepies aktiwiste wat partyskappe in die kerk moet indra.

Hy beoog 'n wêreldkerk vir 'n wêreldstaat. Die moraal van hierdie staat word gedra deur 'n nuwe ideologie, naamlik die ekumenisme. Daarom is rasseskeiding kettery wat uitgeroei moet word. Rasse-integrasie word tot belydenis verhef en die rassevraagstuk ter wille van effektiewe uitskakeling in die internasionale politieke arena ingedra. Wat Suid-Afrika betref, word die kerke in die rol van die „Bekennende Kirche” gedwing, terwyl die staat met die tirannie van die Hitler-regime vergelyk word.

Hy open die weg vir gewelddadige verset as 'n ultima ratio op natuurregtelike gronde. As sulke was sy toespraak die woord waarop Mondlane gewag het. Andersyds het hy daarmee die Wêreldraad van Kerke agter die strewe van die Panafrikanistiese "Liberation Movement" ingeswaai.

Visser 't Hooft se teologie is 'n konglomeraat van uitsprake uit die ekumeniese beweging. Sy toespraak getuig van geen kennis van die monargomaggiese geskrifte uit die 16 de eeu nie.

\section{BIBLIOGRAFIE}

A. Ongepubliseerde bronne

1. Argiefmateriaal

1.1 Argief van die Wêreldraad van Kerke, Genève Africa Working Party. Mindolo.

Mindolo Race Meeting.

2. Ongepubliseerde verhandeling

E. Kohl, Die Rassenfrage Südafrikas und die Haltung der Kirchen, Kiel 1964.

B. Gepubliseerde bronne

1. Boeke

J. N. Bakhuizen van den Brink, Handboek der Kerkgeschiedenis, Den Haag, Bert Bakker, Daamen N.V., 1965 DI. 1.

P. Barth, Joannis Calvini Opera Selecta, Monachii in Aedibus, Chr. Kaiser, MCMLXVII, Vol. III. 
P. Barth, Jaannis Calvini Opera Selecta, Monachii in Aedibus, Chr.

Kaiser, MCMLXXIV, Vol. V.

Belydenisskrifte, Gebede en Formuliere van die Nederduitsch Hervormde Kerk van Afrika, Elsiesrivier, N.G. Kerk-uitgewers, 1963.

G. Brillenburg Wurth, Christelike Sedeleer, Pretoria, J. L. van Schaik Beperk 1967.

J. Calvin, Commentaries on the Twelve Minor Prophets, Grand Rapids, Wm. B. Eerdmans Publishing Company, 1950.

H. H. W. de Villiers, Rivonia Operation Mayibuye, Johannesburg, Afrikaanse Pers-Boekhandel, 1964.

$H$. de Vos, Inleiding tot de Ethiek, Nijkerk, G. F. Callenbach N.V. 1959.

Ecumenical Statements on Race Relations, Development of Ecumenical Thought on Race Relations 1937-1964, Geneva, World Council of Churches, 1965.

H. E. Fey, The Ecumenical Advance, A History of the Ecumenical Movement 1948-1968, London, S.P.C.K.. 1970.

P. Freire, Pedagogy of the Oppressed, New York, Herder and Herder, 1972.

L. A. Hewson, Cottesloe Consultation, The Report of the Consultation among South African Member Churches of the World Counc.1 of Churches, Johannesburg 1961.

P. Jacobs, Theologie Reformierter Bekenntnisschriften in Grundzügen. Neukirchen Kreis Moers, Neukirchener Verlag, 1959.

G. Kittel. Theological Dictionary of the New Testament, Grand Rapids. Wm. B. Eerdmans Publishing Company, 1968. Vol. 3.

E. Mondlane. Kampf um Mozambique, Frankfurt, März Verlag, 1970. J. H. Oldham, Foundations of Ecumenical Social Thought, The Oxford Conference Report, Philadelphia, Fortress Press, 1966.

C. T. Onions, The Shorter Oxford English Dictionary on Historical Principles, Oxford, Clarendon Press, 1973.

C. Ordnung, Eduardo Mondlane, Berlin, Union Verlag, 1971.

A. D. R. Polman, Onze Nederlandsche Geloofsbelijdenis, verklaard uit het verleden geconfronteerd met het heden, Franeker, T. Wever. s.j.

K. H. Rengstorf, Das Evangelium nach Lukas, in Das Neue Testament Deutsch Band 3, Göttingen, Vandenhoeck \& Ruprecht, 1969.

M. Teodori. The New Left: A Documentary History, London, Jonathan Cape, 1970.

J. W. Turnbull, Ecumenical Documents on Church and Society 1925 1953, Geneva, World Council of Churches, 1954.

J. van der Graaf, Het Getuigenis, Motief en Effect, Kampen, J. H. Kok. 1973.

G. C. van Niftrik, Kle.ne Dogmatiek, Nijkerk, G. F. Callenbach N.V., 1961.

W. A. Visser 't Hooft, Memoires, Een leven in de oecumene, Amsterdam, Elsevier, 1971.

0 . Weber, Grundlagen der Dogmatik, Neukirchen-Vluyn, Neukirchener Verlag, 1964 Band 1 en 2.

\section{Tydskrifte}

Hervormde Teologiese Studies, Krugersdorp, N.H.W.-Pers, Desember 1962. Jrg. 18. Afl. III.

Die Hervormer, Krugersdorp, N.H.W.-Pers, Mei 1960, Jrg. 51, no. 2 Race Relations in Ecumenical Perspective, Geneva, World Council of Churches, July 1964, no. 5.

Zeitschrift für Re? gionspädagogik, Dortmund, Crüwell, Verlag, Oktober, 1971, Jrg. 26, Heft 10.

\section{Borsjures en Referaat}

B. J. Engelbrecht, Die Prinsip.ële Patroon van die Calvinisme in S.A., Referaat gelewer by die Simposium van die Instituut vir die Bevordering van Calvinisme te Potchefstroom op 10 April 1969.

A. H. Murray, The Vindicae Contra Tyrannos, (Cape Town) University of Cape Town, 1966.

F. Zipfel, Gedenkstätte Plötzensee Berlin, Berlin, Colloquium Verlag, 1972. 